\title{
An evaluation of changes in a mountainous rural landscape of Northeast Portugal using remotely sensed data
}

\author{
Isabel Pôças ${ }^{\mathrm{a}}$, Mario Cunha ${ }^{\mathrm{b}, *}$, Andre R.S. Marcal ${ }^{\mathrm{c}}$, Luis S. Pereira ${ }^{\mathrm{d}}$ \\ a Faculdade de Ciências da Universidade do Porto and Centro de Engenharia dos Biossistemas, Campus Agrário de Vairão, 4485-661 Vairão, Portugal \\ ${ }^{\mathrm{b}}$ Faculdade de Ciências da Universidade do Porto and Centro de Investigação de Ciências Geoespaciais, Campus Agrário de Vairão, $4485-661$ Vairão, Portugal \\ c Faculdade de Ciências da Universidade do Porto and Centro de Investigação de Ciências Geoespaciais, Departamento de Matemática, Rua do Campo Alegre 687, Porto, Portugal \\ ${ }^{\mathrm{d}}$ Instituto Superior de Agronomia, Universidade Técnica de Lisboa and Centro de Engenharia dos Biossistemas, Tapada da Ajuda, 1349-017 Lisboa, Portugal
}

\section{A R T I C L E I N F O}

Article history:

Received 5 December 2010

Received in revised form 5 February 2011

Accepted 13 February 2011

Available online 16 March 2011

\section{Keywords:}

Landscape dynamics

Semi-natural mountain meadows

Supervised classification

Agroenvironmental policies

Landsat

\begin{abstract}
A B S T R A C T
Image data from Earth Observation Satellites (EOS) were used to analyse mountain landscape changes in Northeast Portugal. Three Landsat images, from April 30th 1979, March 14th 1989 and May 29 th 2002 were used. A supervised classification was performed for each image based on the radiometric information and the Normalised Difference Vegetation Index (NDVI). Eleven classes were selected considering the main land cover types in the region. The classification results showed high overall accuracy (above 92.5\%) and kappa coefficient (above 0.91). Broadly, the range of dates of the Landsat images used allowed for the differentiation between classes. Nevertheless, some problems occurred in differentiating between classes of forest and shrub vegetation due to similar characteristics and vegetation conditions in some periods of the year, and also due to the effects of topographic shadows associated to mountain areas. Meadows and annual crops were the classes having greater changes from 1979 to 2002: meadows area increased $60 \%$ while annual crops decreased $43.5 \%$. The increase in meadows area was likely due to policies supporting agroenvironmental conservation and autochthon bovine livestock production. Differently, the decrease in annual crops was likely due to the loss of economical competitiveness of main annual crops and to the rural population decrease and ageing, which favoured the replacement of arable lands by permanent meadows. These results may help developing policies and measures for sustainable management of traditional mountain rural landscapes.
\end{abstract}

(C) 2011 Elsevier B.V. All rights reserved.

\section{Introduction}

Mountain areas cover 27\% of the earth's land surface (Blyth et al., 2002). Mountainous regions are characterized by landscapes of high biodiversity and cultural value, often related to the traditional ecological knowledge preserved by local communities. Broadly, traditional mountainous rural landscapes reflect a long-term relationship between people and environment that gradually changed an adverse landscape into a suitable source of food and income for mountain populations (Calvo-Iglesias et al., 2008; Lasanta et al., 2006; Rescia et al., 2008).

Particularly since the middle of the last century, landscape changes have been more sudden and have occurred at a broader scale as a result of the impacts of industrialisation, urbanization and, lately, globalization (Antrop, 2005; Calvo-Iglesias et al., 2008). Landscape changes are diverse but very often influenced by regional

\footnotetext{
* Corresponding author. Tel.: +351 252660400; fax: +351252661780.

E-mail addresses: ipocas@mail.icav.up.pt (I. Pôças), mcunha@mail.icav.up.pt (M. Cunha), andre.marcal@fc.up.pt (A.R.S. Marcal), lspereira@isa.utl.pt (L.S. Pereira).
}

and agricultural policies. Apparently, the main trend of actual European landscape changes relates to the polarization between a more intensive use of land in most favourable areas and a more extensive use, or even land abandonment, in remote rural areas having less favourable economic and environmental conditions such as mountain areas (Antrop, 2005).

The traditional landscape of the mountainous region of Northeast Portugal is characterized by the ancestral agro-pastoral system, as in other European areas (Calvo-Iglesias et al., 2008; Mottet et al., 2006). It combines a mix of land uses: mountain semi-natural meadows ("lameiros") and common lands ("baldios") extensively used for hay and grazing; crop fields; vegetable gardens located close to the villages; and evergreen and deciduous forests (Pôças et al., 2009). This landscape integrates a cultural heritage value and is recognized by its ecological value, particularly related with the conservation of plant and animal biodiversity and with protected habitats (e.g. "lameiros" are identified as Natura 2000 habitat, code 6510). Furthermore, it is considered of great interest for tourism, particularly in regards to nature trails. Nevertheless, this region is now threatened by an ageing and decrease of the population, which creates problems of sustainability for the 
ancestral mountain landscapes over short to medium temporal scales.

Recognizing recent landscape changes and their driving forces is crucial for preserving landscapes and their ecological and cultural values, as well as enhancing life conditions in mountain regions. Monitoring and mapping the landscapes over successive decades, including the quantification of their characteristic elements and respective spatial relations, allows for the analysis of the impacts of management and land use on sustainability and preservation throughout time (Narumalani et al., 2004). Critical to understanding landscape changes is the existence of sources of historical information that may provide a baseline description. During the last years much effort has been made to improve the integration and interpretation of different types of data to detect land use and land cover changes, including historical maps, statistical census, field surveys, aerial photographs and satellite images (e.g. CalvoIglesias et al., 2008; Lucas et al., 2007; Mottet et al., 2006; Pelorosso et al., 2009; Petit and Lambin, 2001; Rogan et al., 2008). With the advent of remote sensing technology, image data acquired by Earth Observation Satellites (EOS) provide a synoptic and repetitive coverage of large areas through time. In this context Landsat imagery is particularly interesting due to its continued coverage since the 1970 s with a new satellite launch already planned for 2012 (Landsat Data Continuity Mission), which will extend Landsat records for several years more (Houet et al., 2010). Nevertheless, using remote sensing data to map land use in mountain regions present several difficulties due to the high slope angles, topographic shadowing, complex land cover patterns, and large spatial diversity specially when fragmentation is high (Millette et al., 1995; Poudel, 2008; Weiss and Walsh, 2009; Wundram and Löffler, 2008).

Several algorithms have been developed for change detection studies, including post-classification comparison, image differencing, principal component analysis, and image regression among others (e.g. Bayarsaikhan et al., 2009; Castellana et al., 2007; Foody, 2002; Macleod and Congalton, 1998; Ridd and Liu, 1998).

The objectives of this study are, firstly, to evaluate the land use changes in a mountain rural landscape of Northeast Portugal from 1979 to 2002 using remote sensing imagery; secondly, to infer the impacts of agricultural policies and demography over the past decades on the landscape dynamics. To achieve the first goal, widespread methods already proved accurate were adopted, as it is the case of maximum likelihood classification, accuracy assessment and temporal change detection (Bayarsaikhan et al., 2009; Millette et al., 1995).

\section{Materials and methods}

\subsection{Study area}

The study area is located in Montalegre municipality, in the mountain region of Northeast Portugal, between latitudes of $41^{\circ} 34^{\prime} 47^{\prime \prime}$ and $41^{\circ} 56^{\prime} 34^{\prime \prime} \mathrm{N}$ and longitudes of $7^{\circ} 33^{\prime} 23^{\prime \prime}$ and $8^{\circ} 08^{\prime} 03^{\prime \prime} \mathrm{W}$ (Fig. 1). The landscape of Montalegre is typical of traditional mountain agrarian systems. It combines a mixture of land uses in fragmented arrangement that constitute a small-scale hamlet system (Pinto-Correia and Vos, 2004).

The main features of this mountain landscape fit the archetypal organization of the European countryside of Roman origin represented by ager, saltus and silva (Claval, 2007; Mazoyer and Roudart, 1997). The heart of this agrarian landscape trilogy is occupied by the village buildings (domus) and vegetable gardens (hortus). The hortus consists of small fields, located near the villages, usually irrigated and having fertile soils, in which fresh vegetables, medicinal herbs and fruits are grown. The ager consists of cropped

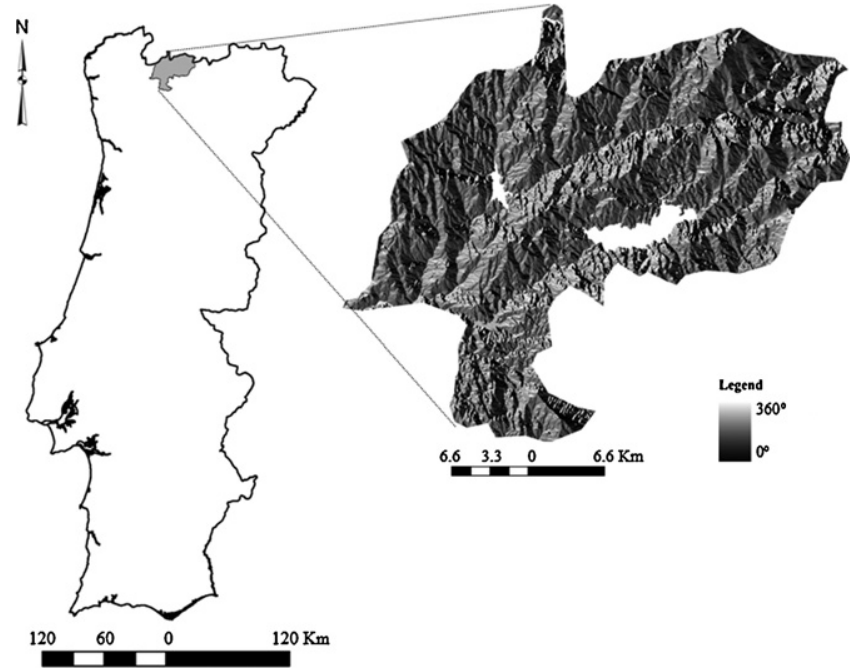

Fig. 1. Location of the study area (Montalegre) in the Northeast of Portugal and detail of the aspect map of Montalegre.

fields, where mainly rye and potato are grown. The saltus is a non-cropped area that includes irrigated permanent semi-natural meadows ("lameiros"), used for grazing and hay production, and common lands ("baldios"), a mix of herbaceous and shrubs used for extensive grazing. Both constitute the main fodder resource for livestock production, thus playing a main role in the farming economy. The silva, usually located in rugged relief zones, is represented by evergreen forests, mainly Pinus pinaster, and deciduous forests, including oaks, chestnuts and riparian species as birch.

\subsection{Satellite imagery and data processing}

Three EOS images were used: Landsat2 MSS from April 30th 1979, Landsat5 TM from March 14th 1989 and Landsat7 ETM+ from May 29th 2002 (path 204/row 31), therefore covering a period of 24 years. The images were selected within the Landsat historical archive and refer to similar periods of the year. Differences in dates from the three years result from the fact that images should be free of clouds, which often occur in the area. Landsat imagery has been used previously for landscape change studies in mountain areas with similar characteristics (e.g. Romero-Calcerrada and Perry, 2004; Serra et al., 2008).

The image from 2002 was acquired with L1T processing level (geometric and terrain correction) and projected in the UTM coordinates system (WGS 84 datum, projection UTM Zone 29N). The images from 1979 and 1989 were ortho-rectified using the image from 2002 as reference. A digital elevation model from Montalegre with a pixel of $30 \mathrm{~m}$ was used as elevation reference in the ortho-rectification procedure. Ground control points (GCP) adjusted according to the elevation reference were marked over the 2002 Landsat image and the Landsat images to ortho-rectify. Each GCP was selected in easily identifiable locations in both the reference and uncorrected images. In the 1979 Landsat2 MSS image, $20 \mathrm{GCP}$ were identified with an associated root mean square (RMS) of $0.63 \times 0.76$ pixels; in the 1989 Landsat5 TM image, 22 GCPs were identified with a RMS of $0.35 \times 0.37$ pixels. The two images were geometrically corrected using the nearest neighbour resampling method. This resampling algorithm is considered appropriate for classification studies because it simply re-arranges the pixels position, maintaining their radiometric integrity (Richards and Jia, 2006). Previously to the ortho-rectification of the 1979 Landsat2 MSS image, the pixels size was converted 
Table 1

Classes considered for the supervised classification and corresponding training areas and validation per class and image.

\begin{tabular}{|c|c|c|c|c|c|c|}
\hline \multirow[t]{2}{*}{ Classes } & \multicolumn{3}{|c|}{ Training areas (number of pixels) } & \multicolumn{3}{|c|}{ Validation areas (number of pixels) } \\
\hline & 30 April 1979 & 14 March 1989 & 29 May 2002 & 30 April 1979 & 14 March 1989 & 29 May 2002 \\
\hline Meadows (MW) & 3811 & 8529 & 4967 & 243 & 174 & 157 \\
\hline Annual crops (AC) & 426 & 160 & 70 & 182 & 86 & 42 \\
\hline Sparse vegetation (SV) & 1424 & 415 & 666 & 445 & 179 & 89 \\
\hline Closed heathlands $(\mathrm{CH})$ & 520 & 301 & 189 & 166 & 94 & 98 \\
\hline Open heathlands $(\mathrm{OH})$ & 798 & 559 & 365 & 366 & 209 & 312 \\
\hline Low shrublands (LS) & 1478 & 487 & 373 & 443 & 413 & 373 \\
\hline Deciduous forests (DF) & 154 & 60 & 32 & 220 & 127 & 53 \\
\hline Evergreen forests (EF) & 1334 & 2331 & 2410 & 498 & 381 & 109 \\
\hline Bare soil/rock (BS) & 176 & 690 & 525 & 106 & 70 & 84 \\
\hline Urban areas (UA) & 254 & 212 & 186 & 74 & 96 & 41 \\
\hline Water (WT) & 12,397 & 7150 & 11,055 & 1101 & 1128 & 752 \\
\hline
\end{tabular}

from $57 \mathrm{~m}$ to $30 \mathrm{~m}$ using the nearest neighbour resampling algorithm.

The classification of all Landsat images was based on the radiometric information from reflectance bands (1-5 and 7 for TM/ETM+ bands, 1-4 for MSS) and the Normalised Difference Vegetation Index (NDVI), as formulated by Rouse et al. (1973):

$\mathrm{NDVI}=\frac{\rho_{\mathrm{NIR}}-\rho_{\text {red }}}{\rho_{\mathrm{NIR}}+\rho_{\text {red }}}$

where $\rho_{\text {NIR }}$ and $\rho_{\text {red }}$ are the surface reflectance for the near infrared (NIR) and red wavelength bands, respectively. The spectral range of the red and NIR bands slightly varies with the Landsat sensor: $697-802 \mathrm{~nm}$ and $807-990 \mathrm{~nm}$ in the Landsat2 MSS; 626-693 nm and 776-994 nm in Landsat5 TM; and 631-692 nm and $772-898 \mathrm{~nm}$ in Landsat ETM+ (Chander et al., 2009).

\subsection{Field site training and testing data base}

The classification was implemented over a rectangular subset (1317 lines $\times 1614$ columns) of the Landsat images, including all Montalegre area. In the post-classification stage, a mask to limit the classification results to the area of interest was applied. The supervised classification was implemented by selecting eleven classes based on the main land cover types identified in the region: meadows, annual crops, sparse vegetation, closed heathlands, open heathlands, low shrublands, deciduous forests, evergreen forests, bare soil and rocks, urban areas and water. Sparse vegetation refers to very sparse foliage cover $(<10 \%)$ dominated by grasses and herbs, and few shrubs. Closed heathlands refers to shrubs with dense foliage cover (70-100\%), open heathlands to shrubs with mid-dense foliage cover (30-70\%), and low shrublands to shrubs of sparse foliage cover (10-30\%). In these three last classes also occur few grasses and herbs. The common lands mainly include vegetation of these four types.

Training areas were selected for each of the eleven classes considered. They consist of a set of pixels identified over well-known areas in each Landsat image, thus providing a reference spectral signature per class. The selection of training areas per image allowed minimizing the impact of the differences in the time of acquisition of the three Landsat images. The identification of these training areas was supported by an orthophotomap of 2003 (0.5 m spatial resolution) and by information gathered from field surveys. The number of training pixels per class was defined as a function of the number of spectral bands in each image $(N)$. At least $N+1$ training pixels per class were considered, whenever possible more than $N \times 10$, as recommend by several authors (e.g. Richards and Jia, 2006). Several pixels per training areas were selected for each Landsat image (Table 1).

The Bhattacharrya distance was computed over the training areas to infer the separability between the various classes (Choi and Lee, 2003; Richards and Jia, 2006). The Bhattacharrya distance ranges between 0 and 2, with 0 representing a complete overlap between two classes, and 2 representing a complete separation between two classes in the feature space. Bhattacharrya distances above 1.9 correspond to good class separability (Richards and Jia, 2006).

The supervised classification was implemented using the maximum likelihood algorithm (Richards and Jia, 2006), which assumes a normal distribution of each class spectral pattern (Xie et al., 2008). This statistical assumption was confirmed by the histogram analysis of the spectral pattern of the training areas for each band. In each Landsat image, a set of pixels of each land cover type was selected and used as validation areas for the classification (Table 1). The maximum likelihood classifier does not consider any relation between the pixel to classify and its neighbours, thus making possible the production of "salt and pepper" noise in the maps resulting from classification (Lu and Weng, 2007). In order to reduce this effect, mode filters of $3 \times 3,1 \times 3$ and $3 \times 1$ were applied to the Landsat-derived maps. The software Geomatica v8.2 (PCI Geomatics, 2001) was used for the Landsat images ortho-rectification and classification procedures.

\subsection{Accuracy assessment}

The accuracy of the Landsat-derived maps was assessed by confusion matrices using the percentage of pixels classified per class, the overall accuracy and the kappa coefficient (Foody, 2002). The overall accuracy corresponds to the percentage of pixels correctly allocated to each class and is computed across the main diagonal of the confusion matrix. The kappa coefficient takes into consideration both the pixels in the main diagonal and the marginal values in the confusion matrix (Foody, 2002; Richards and Jia, 2006). This accuracy assessment was performed over the training and validation areas (Table 1 ).

The results of classification for each image were compared with other data sources: (i) statistical data from the agricultural census of 1979, 1989 and 1999 (INE, 2001); (ii) CORINE Land Cover data from 2000 (EEA, 2000); (iii) information gathered from field surveys; (iv) forestry inventory from 1995-1998; and (v) "baldios" inventory data. The agricultural census collect data from agro-forestry farms that produce agricultural products, while the forestry inventory was carried out purposefully to quantify forest areas, thus both not covering the same areas. Therefore, data relative to forest areas obtained from the forestry inventory are more reliable than those from the agricultural census; differently data from this census are more reliable relative to agricultural crops. These data were used as a general benchmark to determine whether the class areas in the Landsat-derived maps were representative of the reported class areas for Montalegre, and to identify any major under- or overestimation of a specific class. 
Table 2

Confusion matrices (in percentage values) and statistical accuracy assessment defined for the classification results over the training areas for each Landsat image.

\begin{tabular}{|c|c|c|c|c|c|c|c|c|c|c|c|}
\hline Classes & WT & BS & UA & MW & AC & $\mathrm{EF}$ & DF & SV & $\mathrm{OH}$ & $\mathrm{CH}$ & LS \\
\hline \multicolumn{12}{|c|}{ April 30th 1979} \\
\hline WT & 99.3 & 0.0 & 0.0 & 0.0 & 0.0 & 0.7 & 0.0 & 0.0 & 0.0 & 0.0 & 0.0 \\
\hline BS & 0.0 & 100.0 & 0.0 & 0.0 & 0.0 & 0.0 & 0.0 & 0.0 & 0.0 & 0.0 & 0.0 \\
\hline UA & 0.0 & 0.0 & 96.9 & 0.0 & 0.0 & 0.0 & 3.1 & 0.0 & 0.0 & 0.0 & 0.0 \\
\hline MW & 0.0 & 0.0 & 0.0 & 99.8 & 0.0 & 0.0 & 0.0 & 0.0 & 0.0 & 0.0 & 0.2 \\
\hline AC & 0.0 & 0.0 & 0.0 & 0.0 & 100.0 & 0.0 & 0.0 & 0.0 & 0.0 & 0.0 & 0.0 \\
\hline $\mathrm{EF}$ & 0.0 & 0.0 & 0.0 & 0.0 & 0.0 & 99.0 & 0.0 & 0.0 & 0.0 & 0.0 & 1.0 \\
\hline DF & 0.0 & 0.0 & 0.0 & 0.0 & 0.0 & 0.0 & 100.0 & 0.0 & 0.0 & 0.0 & 0.0 \\
\hline SV & 0.0 & 0.0 & 0.0 & 0.0 & 0.0 & 0.0 & 0.0 & 100.0 & 0.0 & 0.0 & 0.0 \\
\hline $\mathrm{OH}$ & 0.0 & 0.0 & 0.0 & 0.0 & 0.0 & 0.0 & 0.5 & 0.5 & 99.0 & 0.0 & 0.0 \\
\hline $\mathrm{CH}$ & 0.0 & 0.0 & 0.0 & 0.0 & 0.0 & 0.0 & 3.5 & 0.0 & 0.0 & 96.5 & 0.0 \\
\hline LS & 0.0 & 0.0 & 0.0 & 0.0 & 0.0 & 2.2 & 0.0 & 0.0 & 0.0 & 1.0 & 96.8 \\
\hline \multicolumn{12}{|c|}{ Overall accuracy 98.8\%; kappa coefficient 0.99} \\
\hline \multicolumn{12}{|c|}{ March 14th 1989} \\
\hline WT & 86.3 & 0.0 & 0.0 & 0.0 & 0.0 & 12.8 & 0.0 & 0.0 & 1.0 & 0.0 & 0.0 \\
\hline BS & 0.0 & 98.6 & 0.9 & 0.0 & 0.1 & 0.0 & 0.0 & 0.1 & 0.3 & 0.0 & 0.0 \\
\hline UA & 0.0 & 7.5 & 90.6 & 0.0 & 1.9 & 0.0 & 0.0 & 0.0 & 0.0 & 0.0 & 0.0 \\
\hline MW & 0.0 & 0.0 & 0.0 & 99.2 & 0.4 & 0.2 & 0.0 & 0.0 & 0.0 & 0.0 & 0.1 \\
\hline AC & 0.0 & 0.0 & 0.0 & 0.0 & 100.0 & 0.0 & 0.0 & 0.0 & 0.0 & 0.0 & 0.0 \\
\hline $\mathrm{EF}$ & 0.1 & 0.0 & 0.0 & 0.0 & 0.0 & 95.3 & 0.0 & 0.0 & 0.4 & 0.0 & 4.1 \\
\hline DF & 0.0 & 0.0 & 0.0 & 0.0 & 0.0 & 0.0 & 100.0 & 0.0 & 0.0 & 0.0 & 0.0 \\
\hline SV & 0.0 & 11.6 & 0.0 & 0.0 & 0.0 & 0.0 & 0.7 & 87.5 & 0.2 & 0.0 & 0.0 \\
\hline $\mathrm{OH}$ & 0.0 & 0.0 & 0.0 & 0.0 & 0.0 & 0.0 & 0.0 & 0.5 & 97.5 & 0.0 & 2.0 \\
\hline $\mathrm{CH}$ & 0.0 & 0.0 & 0.0 & 0.0 & 0.7 & 0.0 & 0.0 & 0.0 & 0.0 & 99.3 & 0.0 \\
\hline LS & 0.0 & 0.0 & 0.0 & 0.0 & 0.0 & 2.7 & 0.0 & 0.0 & 2.5 & 0.0 & 94.9 \\
\hline \multicolumn{12}{|c|}{ Overall accuracy 95.4\%; kappa coefficient 0.91} \\
\hline \multicolumn{12}{|c|}{ May 29th 2002} \\
\hline WT & 99.4 & 0.4 & 0.0 & 0.0 & 0.0 & 0.0 & 0.0 & 0.0 & 0.2 & 0.0 & 0.0 \\
\hline BS & 0.0 & 99.4 & 0.0 & 0.0 & 0.0 & 0.0 & 0.0 & 0.6 & 0.0 & 0.0 & 0.0 \\
\hline UA & 0.0 & 1.1 & 98.9 & 0.0 & 0.0 & 0.0 & 0.0 & 0.0 & 0.0 & 0.0 & 0.0 \\
\hline MW & 0.0 & 0.0 & 0.0 & 99.6 & 0.0 & 0.0 & 0.4 & 0.0 & 0.0 & 0.0 & 0.0 \\
\hline AC & 0.0 & 0.0 & 0.0 & 0.0 & 100.0 & 0.0 & 0.0 & 0.0 & 0.0 & 0.0 & 0.0 \\
\hline $\mathrm{EF}$ & 0.0 & 0.0 & 0.0 & 0.0 & 0.0 & 99.2 & 0.0 & 0.0 & 0.5 & 0.0 & 0.4 \\
\hline DF & 0.0 & 0.0 & 0.0 & 0.0 & 0.0 & 0.0 & 100.0 & 0.0 & 0.0 & 0.0 & 0.0 \\
\hline SV & 0.0 & 5.0 & 0.0 & 0.0 & 1.1 & 0.0 & 0.0 & 94.0 & 0.0 & 0.0 & 0.0 \\
\hline $\mathrm{OH}$ & 0.0 & 0.0 & 0.0 & 0.0 & 0.0 & 0.0 & 0.0 & 0.0 & 99.7 & 0.0 & 0.3 \\
\hline $\mathrm{CH}$ & 0.0 & 0.0 & 0.0 & 0.0 & 0.0 & 0.0 & 0.0 & 0.5 & 0.0 & 99.5 & 0.0 \\
\hline LS & 0.0 & 0.0 & 0.0 & 0.0 & 0.0 & 1.3 & 0.0 & 0.0 & 9.4 & 4.6 & 84.7 \\
\hline \multicolumn{12}{|c|}{ Overall accuracy 97.7\%; kappa coefficient 0.98} \\
\hline
\end{tabular}

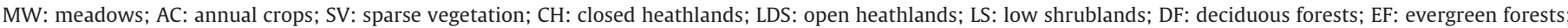
BS: bare soil/rock; UA: urban areas; WT: water.

\section{Results}

\subsection{Separability and accuracy: analysis over the training areas}

The implementation of the supervised classification was preceded by the evaluation of the separability between each pair of classes using training data. The results of the average and minimum separability between classes were inferred by Bhattacharrya distance values for each Landsat image of April 30th 1979, March 14 th 1989, and May 29th 2002. The average separability was 1.993 , 1.994, and 1.996, respectively for the images from 1979, 1989 and 2002. The minimum separability between classes in the image from 1979 was observed for deciduous forests and closed heathlands (1.903). In the image from 1989, the minimum separability was observed between classes of evergreen forests and low shrublands (1.932). Differently, in the image from 2002, the minimum separability was between classes of annual crops and sparse vegetation (1.944). The minimum separability values for each image are likely to result from the proximity between spectral signatures of different classes due to the vegetation characteristics in the considered period of the year. They mainly refer to proximity between deciduous forest (e.g. birch stands) and closed heathlands (e.g. Cytisius spp.), and between annual crops, with low ground cover, and sparse vegetation areas. In the 1979 Landsat2 MSS image, the lower average and minimum separability may also be due to the lower spectral resolution of this image when compared to the others. The downscaling procedure applied to the Landast2 MSS image provided for improved comparability among the images studied but did not increase the level of detail to that of Landsat TM or ETM+ images. Because the results of the separability tests were good (values higher than 1.9 for all the images), the set of classes defined above was maintained and the classification algorithm based on the training areas selected was implemented.

The confusion matrices based on the Landsat-derived maps were used to evaluate the percentage of pixels correctly allocated to each class from the training areas (Table 2). The overall accuracy and kappa coefficients were computed for the training areas of each image (Table 2). The overall accuracy was high: $98.8 \%, 95.4 \%$ and $97.7 \%$ for the images of 1979,1989 and 2002, respectively; the kappa coefficients were also high: $0.99,0.91$ and 0.98 for those years (cf. Keuchel et al., 2003). The lower value of the kappa coefficient was observed for the image of 1989 (0.91) due to misclassified pixels in the training areas, particularly water pixels misclassified as evergreen forests (12.8\%) and sparse vegetation pixels misclassified as bare soil or rock (11.6\%), which casually have some sparse vegetation (Table 2 ).

The accuracy results are generally in agreement with the separability results. Nevertheless, for the 1989 Landsat-derived map there were several cases of misclassified pixels distributed over different classes. This lower accuracy relates with the poor illumination conditions of this image, likely because it refers to late winter, as confirmed by the analysis of the histograms of each band (Appendix 
A). For all the bands, this image showed narrower histograms than the other Landsat images, thus indicating poor contrast.

\subsection{General classification}

The classification accuracy was tested over the validation areas defined for each class. The overall accuracy was $92.6 \%$ in the image from $1979,92.1 \%$ in the image from 1989 and $92.8 \%$ in the image from 2002; the kappa coefficient was $0.93,0.88$ and 0.94 for the same images.

Broadly, the application of a mode filter $3 \times 3$ to the classification maps maintained or improved the overall accuracy and the kappa coefficient: overall accuracy of $92.5 \%$ in the image from $1979,93.1 \%$ in the image from 1989, and $95.2 \%$ in the image from 2002; the kappa coefficients were $0.93,0.91$ and 0.96 for the same images respectively. However, the results for the image of 1979 did not improve with that filter application. The application of other filter windows $(1 \times 3$ and $3 \times 1)$ was also tested but the kappa coefficient remained at 0.93 while the overall accuracy only slightly improved, from $92.2 \%$ to $92.6 \%$ (Appendix B). The lower impact of the mode filter application on the image from 1979 is likely due to the referred conversion of the pixel size from 57 to $30 \mathrm{~m}$. This procedure led to a multiplication of the values from the original pixels that favoured a reduction of the noise produced in the classified maps. Differently, the filter application to the classification maps obtained for the images of 1989 and 2002 increased the percentage of pixels correctly classified in the validation areas. The exception was the "annual crops" class, probably due to the small number of pixels per patch in this class associated with a small size of related crop fields.

The percentage of pixels correctly classified in the validation areas was higher than $80 \%$ in all classes and images, which can be considered satisfactory (Keuchel et al., 2003). Therefore, results indicate appropriate accuracy for the intended analysis. The final classification maps (with a $3 \times 3$ mode filter) resulting from the classification of the images are shown in Fig. 2.

The areas per class derived from the Landsat images classification (mode filter $3 \times 3$ ) were computed (Table 3 ). Results show that the landscape of Montalegre is mostly occupied by shrublands and heathlands, which characteristically occur in the common lands ("baldios"). Between 1979 and 2002, meadows increased by approximately 7600 ha and annual crops decreased by approximately 3300 ha. These are the vegetation classes with greater changes (Table 3 ). It is likely that most of those cropped areas were converted into meadows (Appendix C).

Forest classes estimated from image classification show a small increase between 1979 and 2002 (12,365 and 13,057 ha, respectively); however, there was a clear decrease in 1989 (8996 ha, Table 3). When both deciduous forests and evergreen forests classes are analysed individually, the area of evergreen forests slightly decreased ( -728.9 ha).

Most of the area of sparse vegetation, open heathlands, closed heathlands and low shrublands is included in the common lands ("baldios"). The area of sparse vegetation, closed heathlands and low shrublands has shown only a small variation between 1979 and 2002 , corresponding to a coefficient of variation $<0.08$. The classification results for the class of open heathlands shows an increase of around 3700 ha between 1979 and 1989 and a decrease of 6233 ha between 1989 and 2002 (Table 3). This might be due to the conversion of private lands of this class into other classes of shrub vegetation (Appendix $\mathrm{C}$ ) following changes in the traditional grazing activity in common lands (Santos and Aguiar, 1995) or due to the ecological succession processes.

The highest coefficients of variation refer to the water and bare soil/rock classes, with 0.38 and 0.58 , respectively (Table 3 ). The differences between 1979 and 2002 are likely to be related with the

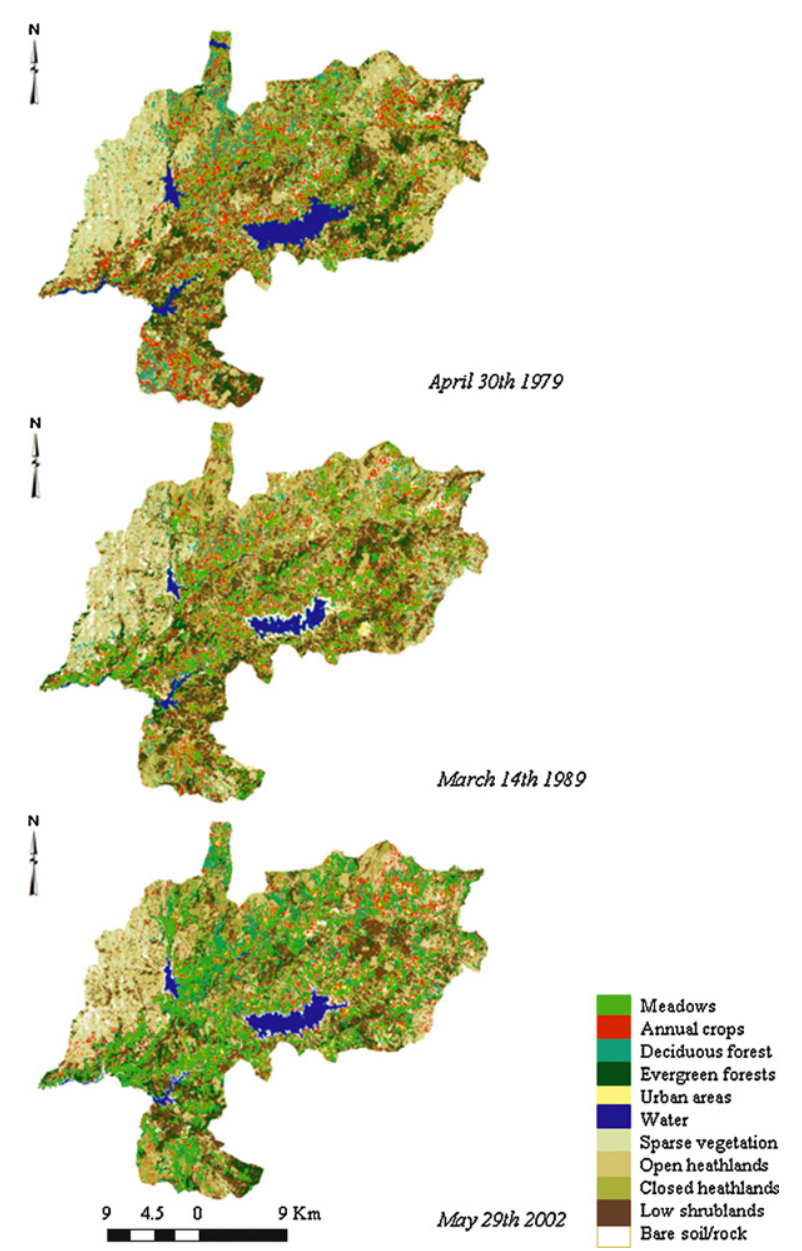

Fig. 2. Final classification maps derived from Landsat images from April 30th 1979, March 14th 1989 and May 29th 2002.

water level in the dam reservoirs that exist in Montalegre. They refer directly to the area occupied by surface water and to the area of reservoir margins, which are classified in the bare soil and rock class (Appendix C). This relation is particularly evident for the image classification results of 1979 and 1989: in 1979 the larger water area ( 3045 ha) is associated with the smaller area of bare soil and rocks (621 ha), while in 1989 an area of 1374 ha of water is associated with 2551 ha of bare soil and rock.

\section{Discussion and conclusions}

This study assessed the temporal landscape changes in a mountain region of Northeast Portugal between 1979 and 2002. The impacts of the demographic fluxes and agricultural policies during this period on those changes are discussed.

The separability results among the classes selected to characterize the landscape and the accuracy obtained over the training and validation areas indicate a good adequacy of the classification procedures implemented. Broadly, the Landsat images dates considered for the study (from late winter until middle spring) allowed for the differentiation between classes. Nevertheless there were some problems in differentiating between classes whose characteristics and vegetation conditions are similar in the period of the year studied.

The areas of meadows and annual crops in the Landsat-derived maps were in agreement with the statistical data from the agricultural census (Fig. 3). However, there is a discrepancy on the 
Table 3

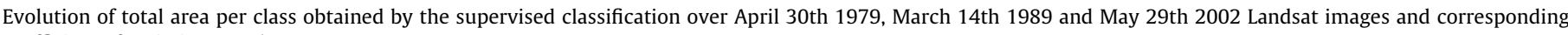
coefficient of variation per class.

\begin{tabular}{|c|c|c|c|c|c|c|c|c|}
\hline \multirow[t]{3}{*}{ Classes } & \multicolumn{6}{|c|}{ Total area per class } & \multicolumn{2}{|c|}{ Variation 1979-2002 } \\
\hline & \multicolumn{2}{|l|}{1979} & \multicolumn{2}{|l|}{1989} & \multicolumn{2}{|l|}{$2002^{\mathrm{a}}$} & \multirow[t]{2}{*}{ (ha) } & \multirow[t]{2}{*}{$\%$} \\
\hline & (ha) & $\%$ & (ha) & $\%$ & (ha) & $\%$ & & \\
\hline Bare soil/rock (BS) & 620.6 & 0.6 & 2551.3 & 2.5 & 2301.3 & 2.2 & 1680.8 & 73.03 \\
\hline Low shrublands (LS) & $21,884.9$ & 21.2 & $22,791.4$ & 22.1 & $21,139.4$ & 20.5 & -745.6 & -3.53 \\
\hline Closed heathlands $(\mathrm{CH})$ & $17,302.4$ & 16.8 & $15,075.7$ & 14.6 & $15,329.1$ & 14.9 & -1973.3 & -12.87 \\
\hline Sparse vegetation (SV) & 10,194 & 9.9 & 9386.5 & 9.1 & 9215.5 & 8.9 & -978.6 & -10.62 \\
\hline Open heathlands $(\mathrm{OH})$ & 21,144 & 20.5 & $24,855.4$ & 24.1 & $18,622.2$ & 18.1 & -2521.8 & -13.54 \\
\hline Deciduous forests (DF) & 5133 & 5.0 & 3148.7 & 3.1 & 6554.3 & 6.4 & 1421.4 & 21.69 \\
\hline Evergreen forests (EF) & 7231.6 & 7.0 & 5847.7 & 5.7 & 6502.7 & 6.3 & -728.9 & -11.21 \\
\hline Meadows (MW) & 5069 & 4.9 & 8400.6 & 8.2 & $12,663.6$ & 12.3 & 7594.7 & 59.97 \\
\hline Annual crops (AC) & 10,877 & 10.5 & 8939.8 & 8.7 & 7581.7 & 7.4 & -3295.4 & -43.46 \\
\hline Urban area (UA) & 729.4 & 0.7 & 672.1 & 0.7 & 839.3 & 0.8 & 109.9 & 13.09 \\
\hline Water (WT) & 3045.1 & 2.9 & 1374.4 & 1.3 & 2232.4 & 2.2 & -812.7 & -36.41 \\
\hline Total & 103,231 & 100 & 103,043 & 100 & 102,981 & 100 & & \\
\hline
\end{tabular}

a The Landsat7 ETM+ image from May 29th 2002 included 300 ha of area covered by clouds which are not attributed to any of the 11 classes considered in the table.

area of meadows obtained by the 2002 image classification and by the agricultural census of 1999 (INE, 2001), although both indicate an increase in the area of meadows. This difference is most likely due to a change in the interpretation of terminology regarding the meadows crops when they are poorly managed (without irrigation, drainage, fertilization, and/or other management practices) and may show signs of abandonment and high risk of spontaneous re-colonization; the agricultural census from 1989 recorded 498 ha of meadows with poor management while the census of 1999 show that this value increased to 13,755 ha. Nevertheless, the increase of the meadows area for the period between 1979 and 2002 observed by image classification results relates well with the observed increase in livestock: the number of bovines was 11,820 in 1979, and increased to 12,429 in 1989 and 14,159 in 1999 (INE, 2001).

The analysis of the mountain rural landscape dynamics between 1979 and 2002 showed a great increase of the meadows area and a decrease of annual crops. These results highlight the impact of several measures implemented in the region during the period considered, particularly various agro-environmental measures introduced after the CAP reform of 1992. One of these measures refers to the conservation of mountain semi-natural irrigated meadows ("lameiros"). In this region, the meadows are mostly represented by "lameiros" (92\%) as confirmed by field surveys data (Vieira et al., 2000). The allocation of subsidies for "lameiros" conservation through agro-environmental measures (Measure 1.2.3 following the Regulation (CEE) 2078/92 and Decree
85/98, and Measure 33 in the Decree 475/2001 DR108 II Serie) very likely had a great impact on increasing the meadows area and consequently on the landscape mosaic. Furthermore, other agro-environmental measures were adopted to motivate livestock production, particularly related with conservation of autochthon bovine breeds (Measure 18 from Regulation (CEE) 2078/92 and Measure 51 in the Decree 475/2001 DR108), including the certification of meat produced by the autochthon bovine breed "Barrosã" (Order 18/94, DR II Serie). These measures also favoured the conservation of common lands and similar private lands used for livestock production.

Differently, the area of annual crops decreased during the same period (Fig. 3). Data from the agricultural census, show that the area cropped with rye decreased by $43 \%$ between 1979 and 1999 , and the area cropped with potato decreased by one third in this period (INE, 2001). These decreases in rye and potato cropped areas are related with the loss of economical competitiveness of both crops; in case of potato it was earlier produced for seed but certification requirements in agreement with the Common Agricultural Policy (CAP) led to the abandonment of this production by most farmers (Bernardo et al., 1992). The decline in cropped areas also relates with both population decrease and ageing, which led to a decrease of labour availability for those crops. These conditions, together with the subsidies referred above favoured the conversion from annual crops into permanent crops, mostly “lameiros". In fact, between 1979 and 1999, the rural population decreased from 14,309 to 7328 individuals, i.e. nearly $50 \%$, and the percentage of population older than

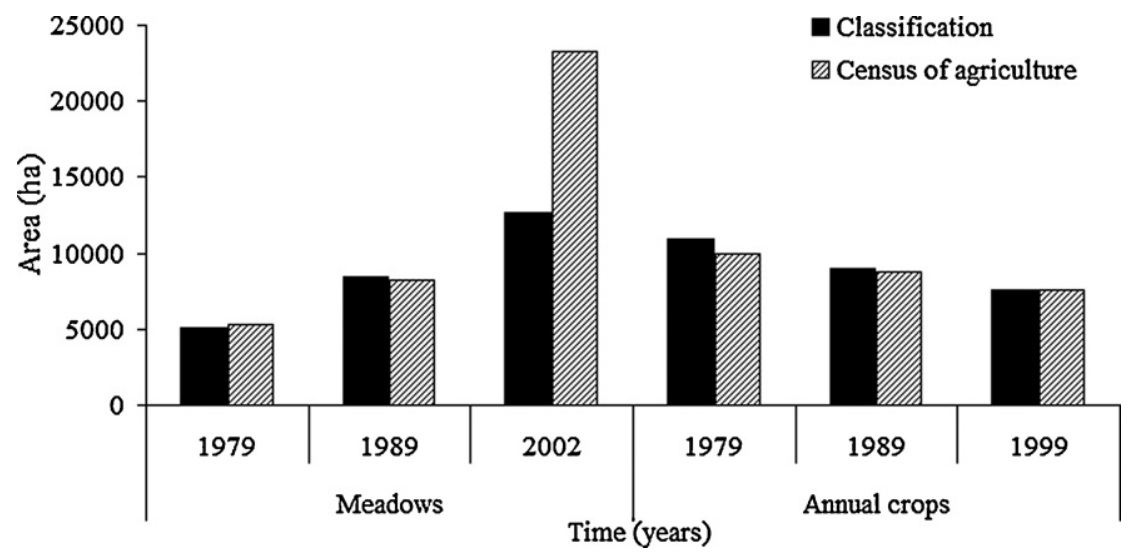

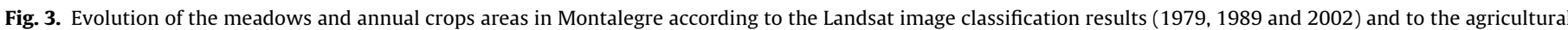
census from 1979, 1989 and 1999 (INE, 2001). 
55 years increased from $28 \%$ to $42 \%$, while the younger population (<34 years) decreased from 50\% to $34 \%$ (INE, 2001). Depopulation and ageing are largely due to lack or failure of regional policies to fix population in mountain areas and to create jobs in the surrounding areas.

The referred decline in annual crops also results from the relative decrease of commodities prices when compared with the increase in costs of production factors. Thus, farmers replace arable land by these permanent meadows ("lameiros") and opt for meat production. Data on increase of bovine livestock confirms this assumption. This trend towards the substitution of annual crops by permanent meadows could indicate a trend for land use and landscape to become more monotonous, as occurring in other Mediterranean mountain areas (Tasser et al., 2009). Calvo-Iglesias et al. (2008) also reported on the development of permanent pastures at the expense of arable land in Northern Galicia (Spain) following the change of the traditional subsistence mixed farming systems to an agriculture based on cattle production. According to these authors, this change was an effect of some CAP subsidies application. Similar trend was also observed in the Pyrenees (France), with the substitution of crop fields by meadows (Mottet et al., 2006). Differently, other Mediterranean mountain landscapes, e.g. the Italian Central Apennines, show a decline of the extensive agriculture and a reduction of meadowlands mainly due to land abandonment followed by scrubland and later woodland recovery (Pelorosso et al., 2009; Romero-Calcerrada and Perry, 2004). The woody vegetation is considered to be the endpoint of secondary succession in these ecosystems (Rocchini et al., 2006). These differences in the landscape changes in various mountain areas of Europe are likely related with regional and local agricultural policies.

The results indicate a prevalence of classes associated with common lands ("baldios") - sparse vegetation, open and closed heathlands and low shrublands - that are traditionally used in this region for livestock grazing in complement of "lameiros". The inventory of "baldios" (updated between 2006 and 2009) estimated their area as 45,000 ha. This area is smaller than the area assigned to those classes through the classification results for 2002 (64,306 ha). However, those classes relate not only to common lands but also to private lands, which were not considered in the common lands inventory, and usually neither in the agricultural census. The "baldios" are explored in a communitarian regime by the neighbours of each village, in order to provide grass (livestock grazing), firewood, bushes, and forest resources. Therefore their management depends on local decisions, making difficult to identify a global trend for the region. As referred above, the measures favouring autochthon cattle and related certified meat also favoured the conservation of those types of vegetation.

Broadly, the classification results for the forest areas have shown a slight increase between 1979 and 2002. Data from the agricultural census of 1979 record an area of forests of 13,174 ha, thus close to data obtained from remote sensing. However, data of census of 1989 and 1999 are very different, respectively 5381 ha and 3310 ha (INE, 2001). The land use map derived from the CORINE Land Cover 2000 presents an area of forests of 16,337 ha (EEA, 2000), which is closer to estimations from image-based classification than that obtained in the census. In addition, data from the forestry inventory from 1995 to 1998 refer to approximately 16,500 ha of forestry stands, thus indicating an underestimation of forest area in the agricultural census of 1989 and 1999. A disagreement between different sources of data was also observed by
Pelorosso et al. (2009) when comparing data on forest area derived from statistical census and from CORINE CLC2000 and CLC1990, which was attributed to discrepancies in methodologies. The low estimates for the forest area obtained for 1989 may be explained by the fact that the image is from end winter, 14th March 1989, when young forest stands and deciduous forests were more difficult to separate from shrub vegetation. Moreover, the lack of homogeneity in stand types and the effects of topographic shadows associated to mountain areas also contribute to the difficulty in distinguishing forest classes as pointed out by Millette et al. (1995). The classification results for the forest areas may also be related with the agro-environmental measures for the maintenance of abandoned forest areas and the preservation of areas with autochthon trees (mainly oaks and riparian species) and shrub species (Regulation (CEE) 2078/92 and Decree 85/98). However, the impact of these measures is smoothed by the forest fires that often occur in this region: between 1989 and 2001, fire devastated 4560 ha of forest, particularly in 1996 ( 1464 ha) and 2000 (1068 ha) (DGRF, 2008).

The overall classification results suggest a trend for extending livestock production and consequent farming specialisation for meat production of "barrosã" cattle in Montalegre, which may constitute an activity of great interest to boost the economy of this mountain region if supported by efficient strategies for population fixation and rural development policies. Tourism may also play a positive role since the landscape mosaic attracts many town people to walk through the mountain and nature trails.

Data obtained with this study provide a clear picture of the changes occurring in this mountain traditional landscape for three decades. Several issues are identified as the main driving forces of those landscape changes. This information can be a useful tool for the planning and development of regional plans aiming at the conservation of this landscape of great cultural value.

\section{Acknowledgments}

This study was funded by the project LamSatXXI, FCOMP-010124-FEDER-006996, "Fundação para a Ciência e a Tecnologia", Portugal. The first author also acknowledges the same institution for the PhD grant (SFRH/BD/24373/2005). Acknowledgments are also due to Mr. António Moura, from Direcção Regional de Agricultura e Pescas do Norte, for the collaboration in the field surveys and to the farmers of the Paredes do Rio and Salto villages.

\section{Appendix A. Histograms of the bands 2, 3, and 4 from (a) Landsat5 TM image (March 14th 1989) and (b) Landsat7 ETM+ (May 29th 2002)}

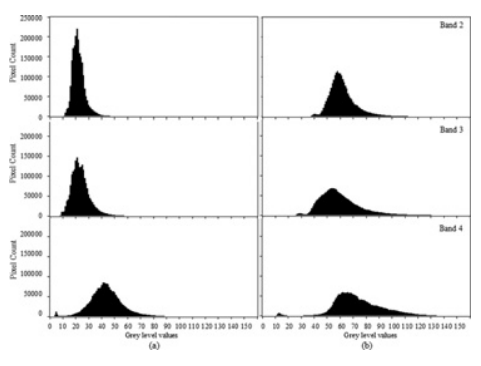


Appendix B. Overall accuracy (in percentage values) and kappa coefficient results over the validation areas for the Landsat-derived maps, with and without filter application

\begin{tabular}{|c|c|c|c|c|c|c|c|c|}
\hline \multirow[t]{2}{*}{ Image date } & \multicolumn{2}{|c|}{ Without filter } & \multicolumn{2}{|c|}{ Filter $3 \times 3$} & \multicolumn{2}{|c|}{ Filter $1 \times 3$} & \multicolumn{2}{|c|}{ Filter $3 \times 1$} \\
\hline & $\begin{array}{l}\text { Overall } \\
\text { accuracy }\end{array}$ & $\begin{array}{l}\text { Kappa } \\
\text { coefficient }\end{array}$ & $\begin{array}{l}\text { Overall } \\
\text { accuracy }\end{array}$ & $\begin{array}{l}\text { Kappa } \\
\text { coefficient }\end{array}$ & $\begin{array}{l}\text { Overall } \\
\text { accuracy }\end{array}$ & $\begin{array}{l}\text { Kappa } \\
\text { coefficient }\end{array}$ & $\begin{array}{l}\text { Overall } \\
\text { accuracy }\end{array}$ & $\begin{array}{l}\text { Kappa } \\
\text { coefficient }\end{array}$ \\
\hline April 30th 1979 & 92.59 & 0.93 & 92.54 & 0.93 & 92.63 & 0.93 & 92.15 & 0.93 \\
\hline March 14th 1989 & 92.12 & 0.88 & 93.14 & 0.91 & 92.60 & 0.90 & 92.46 & 0.91 \\
\hline May 29th 2002 & 92.78 & 0.94 & 95.20 & 0.96 & 94.34 & 0.96 & 94.48 & 0.95 \\
\hline
\end{tabular}

Appendix C. Transition matrix for 1979-2002 period (values in hectares)

\begin{tabular}{|c|c|c|c|c|c|c|c|c|c|c|c|}
\hline & WT & BS & UA & MW & $A C$ & $\mathrm{EF}$ & DF & SV & $\mathrm{OH}$ & $\mathrm{CH}$ & LS \\
\hline WT & 2182 & 450 & 5 & 31 & 50 & 11 & 18 & 65 & 138 & 53 & 43 \\
\hline BS & 0 & 256 & 18 & 11 & 39 & 5 & 25 & 141 & 59 & 41 & 26 \\
\hline UA & 0 & 23 & 372 & 29 & 51 & 5 & 41 & 65 & 60 & 44 & 48 \\
\hline MW & 0 & 79 & 116 & 2826 & 646 & 73 & 493 & 112 & 136 & 393 & 195 \\
\hline$A C$ & 0 & 159 & 274 & 3336 & 2438 & 155 & 1339 & 559 & 512 & 1649 & 456 \\
\hline $\mathrm{EF}$ & 46 & 30 & 12 & 166 & 94 & 2301 & 113 & 219 & 1130 & 385 & 2735 \\
\hline DF & 0 & 26 & 76 & 265 & 209 & 106 & 1554 & 279 & 529 & 1643 & 446 \\
\hline SV & 0 & 712 & 67 & 237 & 812 & 88 & 239 & 3754 & 2682 & 891 & 711 \\
\hline $\mathrm{OH}$ & 7 & 338 & 51 & 573 & 1005 & 748 & 614 & 2611 & 7239 & 2649 & 5308 \\
\hline $\mathrm{CH}$ & 0 & 83 & 59 & 1906 & 990 & 919 & 1787 & 627 & 2492 & 4822 & 3617 \\
\hline LS & 1 & 114 & 61 & 2686 & 594 & 2910 & 1234 & 705 & 3491 & 2748 & 7341 \\
\hline
\end{tabular}

Bold values represent the area per class that remained unchanged between 1979 and 2002.

MW: meadows; AC: annual crops; SV: sparse vegetation; CH: closed heathlands; LDS: open heathlands; LS: low shrublands; DF: deciduous forests; EF: evergreen forests;

BS: bare soil/rock; UA: urban areas; WT: water.

\section{References}

Antrop, M., 2005. Why landscapes of the past are important for the future. Landscape Urban Plan. 70, 21-34.

Bayarsaikhan, U., Boldgiv, B., Kim, K.-R., Park, K.-A., Lee, D., 2009. Change detection and classification of land cover at Hustai National Park in Mongólia. Int. J. Appl. Earth Observ. Geoinform. 11, 273-280.

Bernardo, A., Carvalho, A.C., Barreto, A.L., Cardoso, A.M., Vieira, J.P., Duarte, J.P., Pereira, L.A., 1992. Programa de desenvolvimento agrícola regional do Barroso. Caracterização da zona de incidência do PDAR (Program for the Development of Regional Agriculture in Barroso. Characterization of the Incidence Zone of PDAR). Direcção Regional de Agricultura de Trás-os-Montes, Montalegre (in Portuguese).

Blyth, S., Groombridge, B., Lysenko, I., Miles, L., Newton, A., 2002. Mountain Watch. Environmental Change \& Sustainable Development in Mountains. UNEP World Conservation Monitoring Centre, Cambridge.

Calvo-Iglesias, M.S., Fra-Paleo, U., Dias-Varela, R.A., 2008. Changes in farming system and population as drivers of land cover and landscape dynamics: the case of enclosed and semi-openfield systems in Northern Galicia (Spain). Landscape Urban Plan. 90, 168-177.

Castellana, L., D'Addabbo, A., Pasquariello, G., 2007. A composed supervised/unsupervised approach to improve change detection from remote sensing. Pattern Recogn. Lett. 28, 405-413.

Chander, G., Markham, B.L., Helder, D.L., 2009. Summary of current radiometric calibration coefficients for Landsat MSS, TM ETM+, and EO-1 ALI sensors. Remote Sens. Environ. 113, 893-903.

Choi, E., Lee, C., 2003. Feature extraction based on the Bhattacharyya distance. Pattern Recogn. 36, 1703-1709.

Claval, P., 2007. About rural landscapes: the invention of the Mediterranean and the French school of geography. In: Roca, Z., Spek, T., Terkenli, T., Plieninger, T., Höchtl, F. (Eds.), European Landscapes and Lifestyles: The Mediterranean and Beyond. Edições Universitárias Lusófonas, Lisboa, pp. 1-19.

DGRF, 2008. Incêndios florestais-Totais por concelho (1980-2006)[[nl]]Forest Fires-Totals by Municipality (1980-2006). Ministério da Agricultura, Pescas e Florestas. Direcção-Geral de Recursos Florestais, Available online at http://www.afn.min-agricultura.pt/portal (in Portuguese).

EEA, 2000. Corine Land Cover 2000. European Environment Agency, Available online at http://www.eea.europa.eu/legal/copyright.

Foody, G.M., 2002. Status of land cover classification accuracy assessment. Remote Sens. Environ. 80, 185-201.

Houet, T., Verburg, P.H., Loveland, T.R., 2010. Monitoring and modelling landscape dynamics. Landscape Ecol. 25, 163-167.

INE, 2001. Recenseamentos Gerais da Agricultura, 1979, 1989 and 1999[[nl]]General Agricultural census, 1979, 1989 and 1999. Instituto Nacional de Estatística, Available online at http://inenetw02.ine.pt:8080/biblioteca/search.do (in Portuguese).

Keuchel, J., Naumann, S., Heiler, M., Siegmund, A., 2003. Automatic land cover analysis for Tenerife by supervised classification using remotely sensed data. Remote Sens. Environ. 86, 530-541.
Lasanta, T., González-Hidalgo, J.C., Vicente-Serrano, S.M., Sfrei, E., 2006. Using landscape ecology to evaluate an alternative management scenario in abandoned Mediterranean mountain areas. Landscape Urban Plan. 78, 101114.

Lu, D., Weng, Q., 2007. A survey of image classification methods and techniques for improving classification performance. Int. J. Remote Sens. 28, 823870.

Lucas, R., Rowlands, A., Brown, A., Keyworth, S., Bunting, P., 2007. Rule-based classification of multi-temporal satellite imagery for habitat and agricultural land cover mapping. ISPRS J. Photogramm. 62, 165-185.

Macleod, R.D., Congalton, R.G., 1998. A quantitative comparison of change detection algorithms for monitoring Eelgrass from remotely sensed data. Photogramm. Eng. Remote Sens. 64, 207-216.

Mazoyer, M., Roudart, L., 1997. Histoire des Agricultures du Monde (History of the World Agricultures). Le Seuil, Paris (in French).

Millette, T.L., Tuladhar, A.R., Kasperson, R.E., Turner II, B.L., 1995. The use and limits of remote sensing for analysing environmental and social change in the Himalayan Middle Mountains of Nepal. Global Environ. Change 5, 367-380.

Mottet, A., Ladet, S., Coqué, N., Gibon, A., 2006. Agricultural land-use change and its drivers in mountains landscapes: a case study in the Pyrenees. Agric. Ecosyst. Environ. 114, 296-310.

Narumalani, S., Mishra, D.R., Rothwell, R.G., 2004. Change detection and landscape metrics for inferring anthropogenic processes in the greater EFMO area. Remote Sens. Environ. 91, 478-489.

PCI Geomatics, 2001. Geomatica v.8.2. Copyright ${ }^{\circledR} \mathrm{PCI}$ Geomatics, Ontario, Canada.

Pelorosso, R., Leone, A., Boccia, L., 2009. Land cover and land use change in the Italian central Apennines: a comparison of assessment methods. Appl. Geogr. 29 $35-48$.

Petit, C.C., Lambin, E.F., 2001. Integration of multi-source remote sensing data for land cover change detection. Int. J. Geogr. Inf. Sci. 15, 785-803.

Pinto-Correia, T., Vos, W., 2004. Multifunctionality in Mediterranean landscapes-past and future. In: Jongman, R.H.G. (Ed.), The New Dimensions of the European Landscape. Wageningen FRONTIS Series. Springer, pp. 135-164

Pôças, I., Cunha, M., Marçal, A.R.S., Pereira, L.S., 2009. Los Lameiros pastizales seminaturales de regadio de montaña: sistemas ancestrales en el paisaje rura portugués del siglo XXI. In: Saldaña Martinez, T., Palerme, J., Castro, M., Pereira L.S. (Eds.), Riegos Ancestrales de Iberoamerica. Técnicas y Organización Social del Pequeño Riego (Ancestral Irrigation Systems in Iberoamerica. Techniques and Social Organization of Small Irrigation). Colegio de Postgraduados e Mundi Prensa México, Mexico, DF, pp. 27-40 (in Spanish).

Poudel, K., 2008. Promoting geographic information and earth observation applications for the sustainable development of the Hindu Kush-Himalayan $(\mathrm{HKH})$ region. In: Mountain GIS e-Conference: Geographic Information Earth Observation for the Sustainable Development. International Centre for Integrated Mountain Development (ICIMOD).

Rescia, A.J., Pons, A., Lomba, I., Esteban, C., Dover, J.W., 2008. Reformulating the social-ecological system in a cultural rural mountain landscape in the Picos de Europa region (northern Spain). Landscape Urban Plan. 88, 23-33. 
Richards, J.A., Jia, X., 2006. Remote Sensing Digital Image Analysis. An Introduction, Fourth edition. Springer, Dordrecht.

Ridd, M.K., Liu, J., 1998. A comparison of four algorithms for change detection in an urban environment. Remote Sens. Environ. 63, 95-100.

Rocchini, D., Perry, G.L.W., Salerno, M., Maccherini, S., Chiarucci, A., 2006. Landscape change and the dynamics of open formations in a natural reserve. Landscape Urban Plan. 77, 167-177.

Rogan, J., Franklin, J., Stow, D., Miller, J., Woodcock, C., Roberts, D., 2008. Mapping land-cover modifications over large areas: a comparison of machine learning algorithms. Remote Sens. Environ. 112, 2272-2283.

Romero-Calcerrada, R., Perry, G.L.W., 2004. The role of land abandonment in landscape dynamics in the SPA Encinares del río Alberche y Cofio Central Spain, 1984-1999. Landscape Urban Plan. 66, 217-232.

Rouse, W., Haas, R., Scheel, J., Deering, W., 1973. Monitoring vegetation systems in Great Plains with ERST. In: Proceedings of the Third ERTS Symposium, NASA SP-351 ,. US Government Printing Office, Washington, DC, pp. 309-317.

Santos, J., Aguiar, C., 1995. Private hay meadows and common pastures: integrated management of two ecosystems. In: Albisu, L.M., Romero, C. (Eds.), Environmental and Land Use Issues: An Economic Perspective. Wissenschaftswerlag Vauk, Kiel, pp. 491-501.
Serra, P., Pons, X., Sauri, D., 2008. Land-cover and land-use change in Mediterranean landscape: a spatial analysis of driving forces integrating biophysical and human factors. Appl. Geogr. 28, 189-209.

Tasser, E., Ruffini, F.V., Tappeiner, U., 2009. An integrative approach for analysing landscape dynamics in diverse cultivated and natural mountain areas. Landscape Ecol. 24, 611-628.

Vieira, J., Gonçalves, S., Sanches, D., Bernardo, A., Moreira, N., 2000. Sustentabilidade dos lameiros e do sistema de agricultura de montanha do Norte de Portugal. II. Lameiros (Sustainability of Mountain Seminatural Meadows and Agricultural Systems in Northern Portugal. II. Seminatural Meadows). Actas da $3 \stackrel{a}{a}$ Reunião Ibérica de Pastagens e Forragens, Soc. Portuguesa de Pastagens e Forragens, Bragança-A Coruňa-Lugo, pp. 737-742 (in Portuguese).

Weiss, D.J., Walsh, S.J., 2009. Remote sensing of mountain environments. Geogr. Compass 3, 1-21.

Wundram, W., Löffler, J., 2008. High-resolution spatial analysis of mountain landscapes using a low-altitude remote sensing approach. Int. J. Remote Sens. 29, 961-974.

Xie, Y., Sha, Z., Yu, M., 2008. Remote sensing imagery in vegetation mapping: a review. J. Plant Ecol. 1, 9-23. 